\title{
An Evaluation of the Possible Uses of CNT in Flow Conditions for Removing Humic Substances from Water
}

\author{
Małgorzata Wolska *Di, Zbigniew Ferenc and Anna Solipiwko-Pieścik \\ Department of Environmental Engineering, Wroclaw University of Science and Technology, \\ Wybrzeże Wyspiańskiego 27, 50-370 Wrocław, Poland; zbigniew.ferenc@pwr.edu.pl (Z.F.); \\ anna.solipiwko-piescik@pwr.edu.pl (A.S.-P.) \\ * Correspondence: malgorzata.wolska@pwr.edu.pl
}

check for updates

Citation: Wolska, M.; Ferenc, Z.; Solipiwko-Pieścik, A. An Evaluation of the Possible Uses of CNT in Flow Conditions for Removing Humic Substances from Water. Water 2021, 13, 2160. https://doi.org/10.3390/ w13162160

Academic Editor: Laura Bulgariu

Received: 15 July 2021

Accepted: 4 August 2021

Published: 6 August 2021

Publisher's Note: MDPI stays neutral with regard to jurisdictional claims in published maps and institutional affiliations.

Copyright: (C) 2021 by the authors. Licensee MDPI, Basel, Switzerland. This article is an open access article distributed under the terms and conditions of the Creative Commons Attribution (CC BY) license (https:/ / creativecommons.org/licenses/by/ $4.0 /)$.

\begin{abstract}
This study concerns an evaluation of humic substance removal during an adsorption process on three sorbents: two consisting of carbon nanotubes embedded on a polymer (polypropylene and polyethylene) and granulated active carbon as a reference. The results that were obtained show a significantly lower organic substance removal effectiveness in the case of sorbents containing carbon nanotubes, with an insignificantly lower unit effectiveness $(\mathrm{mg} / \mathrm{g}$ ) of the nanosorbents during first two hours of adsorption. Unfortunately, nanosorbents only allow removing substances with a low molecular weight and high aromaticity, which significantly reduces the possibility of its use in technical conditions for naturally occurring water and the sorption capacity nanotubes were significantly lower in comparison to the GAC.
\end{abstract}

Keywords: carbon nanotubes; sorption; UV absorption; sorption capacity; humic substances

\section{Introduction}

Currently in the world, we can observe a decrease in the available water resources, which is connected with climatic changes, as well as an increase in the water contamination levels, caused mostly by organic substances. Still, in surface water, humic substances are the dominant organic substance type, [1-3], and due to their varied properties, they may present a hazard to human health $[4,5]$. It is because of this that studies have been conducted for many years aiming to evaluate the effectiveness of water treatment unit process and to optimize them for removing organic substances.

A large organic substance removal effectiveness was found for the adsorption process, which is almost $100 \%$ effective in removing Dissolved Organic Carbon (DOC) [6,7]. The most commonly used sorbents in water treatment process are carbon sorbents, specifically activated carbon. Therefore, there is ongoing research about modifying activated carbon to obtain an increase in the effectiveness of this process. [8]. Additionally, carbon nanosorbents, including carbon nanotubes and graphene, have been indicated as materials having a large potential for removing organic substances $[9,10]$. Studies concerning single-walled and multi-walled carbon nanotubes were conducted mainly in laboratory conditions and allowed for determining the kinetics of removing organic substances from water $[5,11]$. They were also conducted for one-component solutions and therefore it was determined that the absorption takes place with a pseudo second-order Freundlich isotherm [12]. The large potential of these materials results from their specific surface area, which is larger than that of classic activated carbons [13]. An additional advantage is the ease of nanosorbent regeneration/cleaning with the use of mineral acids [14], which allows for an almost complete regeneration of the sorption potential. From the organic substances (natural organic matter) present in water, nanosorbents mainly remove substances of a low molecular weight $[15,16]$ and high aromaticity. Hyung and Kim have found that large molecular weight molecules may block the active centers, which may significantly limit the sorption potential of this sorbent [17]. 
Due to the size and properties of nanotubes, they have not been used at a technical scale in flow conditions, and they have only been used in membrane separation process as a layer on the membrane surface $[18,19]$. This resulted in a limiting of biofilm formation on the surface of the membrane, which results from the biostatic properties of CNTs [20,21]. Additionally, there was an increase in the contaminant removal effectiveness, including organic contaminants. This means that the use of CNTs in practice requires limiting their mobility. Therefore, it was justified to carry out studies of the effectiveness of removing organic, mainly humic, substances in adsorption on granulated activated carbon and multi-walled carbon nanotubes, which were deposited on the surface of polyethylene and polypropylene.

The main goal of presented research is assessment of the possibility using the CNT in flow conditions, which can be implemented in technical conditions in water treatment plants.

The high potential of CNT using in organic substances removal is presented many studies [22,23], but all of them are in laboratory conditions in jar tests.

\section{Methods and Procedure}

\subsection{Reserach Procedure}

The studies of the adsorption process were performed at a laboratory scale in flow conditions. The installation (Figure 1) allows for simultaneous operation of three filters with a diameter of $4.8 \mathrm{~cm}$. The adsorption process was conducted at a flow speed of $5 \mathrm{~m} / \mathrm{h}$ downwards, which is a speed that is commonly found at technical conditions (this flow speed is commonly used in water treatment plants). Thanks to this it was possible to compare the three sorbents in terms of their effectiveness in removing organic substances from water.

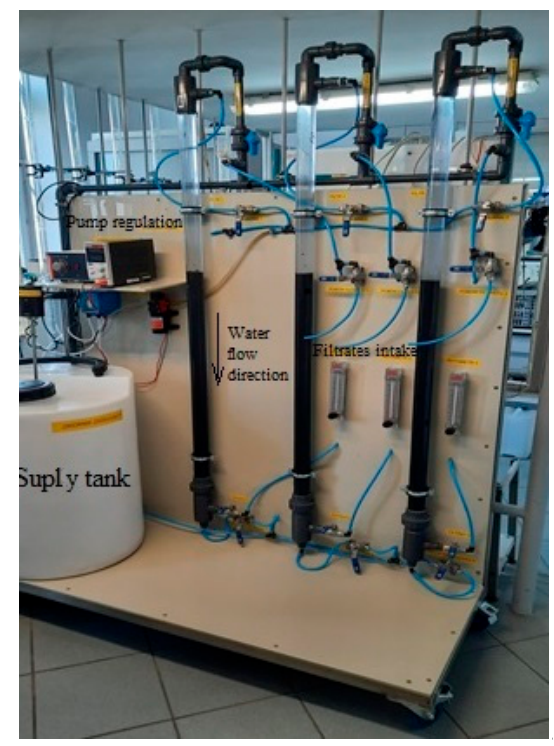

Figure 1. Installation used to implement the adsorption process.

This study used granulated activated carbon (GAC) as the reference material, which is available on the market under the WG-12 trade name, along with two polymer sorbents (polypropylene and polyethylene, respectively) covered with multi-walled carbon nanotubes. The polymer surface (PP and PE) was covered by MWCNT (multi-walled carbon nanotubes) which allowed the use of carbon nanotubes as an adsorption bed in flow conditions. Nanotubes made up 25\% of the sorbent mass in case of both PP and PE based sorbents (MWCNT-PP and MWCNT-PE). The same carbon nanotubes were deposited on the surface of both polymers, and therefore differences in the adsorption effectiveness and the operating conditions are the effect of different properties of the polymers that were used. Both nanosorbents were characterized by a large porosity, which is confirmed by photographs of the surface of the polyethylene-based sorbent (Figure 2). 


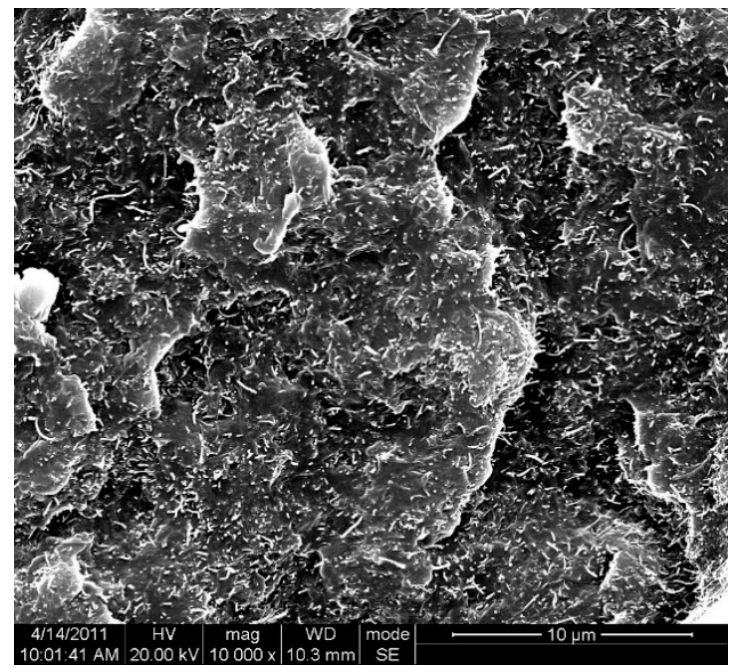

Figure 2. Photograph of the polyethylene sorbent surface.

The adsorption columns were filled with absorption beds depths of $70 \mathrm{~cm}$ (same volume of each sorbents bed), which corresponded to $520 \mathrm{~g} \mathrm{GAC}$ - WG12, $190 \mathrm{~g}$ MWCNT (in the case of MWCNT-PP) and $204 \mathrm{~g}$ MWCNT (in the case of MWCNT-PE).

All the sorbents were immersed in distilled water for $24 \mathrm{~h}$ before the tests, and after filling the columns each sorbent was flushed.

The columns were supplied with tap water enriched with humic acid, with a quantity sufficient to increase the color intensity (340) to about $20 \mathrm{~g} \mathrm{Pt} / \mathrm{m}^{3}$. The solution was prepared in two tanks, $200 \mathrm{dm}^{3}$ each, operating alternatively so that the continuity of column operation could be ensured.

Water for analysis was taken from the supply tank (raw water RW-sample number 1) and from the outflow from each of the MWCNT-PP (sample number 2), MWCNT-PE (sample number 3) and GAC-WG12 (sample number 4) sorption columns (Figure 3). Water from supply tank was pumped to the three parallel filters. The flow direction up-down with flow speed $5 \mathrm{~m} / \mathrm{h}$, were implemented. Filtrates were taken after 1, 3, 6, 7, 9, 12 and $13 \mathrm{~h}$ of sorption column operation, which corresponded to ratios of 7.1 to 92.3 of water volume $\mathrm{V}_{\mathrm{H} 2 \mathrm{O}}$ to the adsorption bed volume $\mathrm{V}_{\mathrm{B}}$. The test was conducted until the exhaustion of the sorption potential of the polymer beds, i.e., until an increase in the filtrate organic substance concentration.

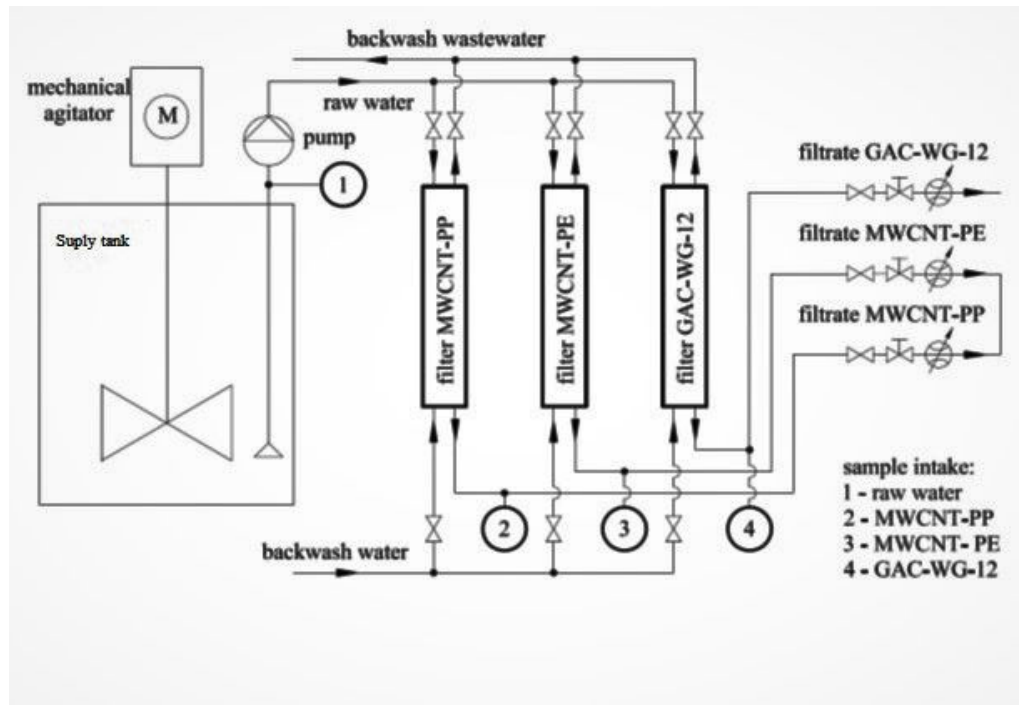

Figure 3. Place of water intake. 


\subsection{Scope and Analytical Methods}

The following parameters were determined for the raw and filtered water: $\mathrm{pH}$, color at a wavelength of $340 \mathrm{~nm}$, which is considered to be the maximum of light absorption by humic substances [24] and at $410 \mathrm{~nm}, \mathrm{UV}$ absorbance at wavelengths of $254 \mathrm{~nm}$ and $272 \mathrm{~nm}$, and the total and dissolved organic carbon concentrations. Based on the DOC concentration and $\mathrm{UV}_{254}$ absorbances, the specific absorbance SUVA was determined.

Additionally, a molecular size distribution analysis using a size-exclusion chromatography (SEC) method was conducted. Thanks to this, the content of molecules with sizes of 2.3-2.5 kDa, 1.8-2.0 kDa, 0.7-0.9 kDa, 0.5-0.7 kDa and smaller than $0.1 \mathrm{kDa}$ was determined.

Analysis of $\mathrm{pH}$ was conducted using $\mathrm{pH}$-meter, while color intensity and UV absorbance was determined by the use of a Shimadzu UV-VIS 1800 spectrophotometer on samples filtered through a $0.45 \mu \mathrm{m}$ filter. The analysis of total and dissolved organic carbon was performed with the use of a Hach TOC analyzer by a thermal method.

SEC analysis was conducted by chromatographic methods. Chromatographic analysis was performed with the use of an Ulti Mate 3000 Dionex liquid chromatograph, equipped with a DAD detector. The results were obtained with detection at $254 \mathrm{~nm}$. A Shodex OH pak SB-803 HQ polymer column with a molecule size of $13 \mu \mathrm{m}$ and dimensions of $8 \times 300 \mathrm{~mm}$ was used, along with a Shodex OHpak SB-G $6 \mathrm{~B}, 10 \mu \mathrm{m}, 6 \times 50 \mathrm{~mm}$ precolumn. An analysis of concentrations of molecules of a given size was performed based on changes of the peak areas in chromatographs. Calibration was performed with the use of polystyrene sulfonate sodium salts (PSS, American Polymer Standards Corporation).

The efficiency of contamination removal was calculated as:

$$
\eta=\frac{C_{0}-C_{e}}{C_{0}} \times 100 ; \%
$$

where: $C_{0}$ parameter value before adsorption; $C_{e}$ - parameter value after adsorption.

\section{Results and Discussion}

The raw water was characterized by a constant physico-chemical composition (Table 1), which allowed for a comparison of the effectiveness of the individual sorbents.

The introduction of humic substances into water caused a significant increase in the color intensity at both $340 \mathrm{~nm}$, as well as $410 \mathrm{~nm}$. Additionally, it is worth to note that the added organic substances were characterized by significant aromaticity, which is shown by the $\mathrm{UV}_{254}$ and $\mathrm{UV}_{272}$ absorbance values [25].

Medium and large molecular weight substances dominated in raw water, which indicates their susceptibility to removal in the adsorption process [26]. In GAC filtrates the concentration of organic substances particles of all sizes decreased. Adsorption by the MWCNT- PP and MWCNT-PE beds significantly decreased concentration of the low molecular weight particles (Figure 4). This means that nanosorbents remove only substances with a defined particle size they are selective sorbents. On the other hand, on the GAC, organic substances are removed non-selectively.

Regardless of the adsorbent used, during the first eight hours a decrease of the organic substance content was found in all water samples. In the case of classic activated carbon (WG-12) this effectiveness was close to $100 \%$, while in the case of the other two sorbents it did not exceed $40 \%$ (Figure 5). In the case of both sorbents containing carbon nanotubes, a high effectiveness was found in the first $2 \mathrm{~h}$ of operation and a significant decrease in the effectiveness after $6 \mathrm{~h}$ of operation. Granulated activated carbon also showed a decrease in the adsorption effectiveness after the same amount of time, yet this decrease was minor and the sorbent still effectively removed organic substances, which is also confirmed by the results of other studies $[27,28]$. 
Table 1. Ranges of water quality parameters before and after adsorption.

\begin{tabular}{|c|c|c|c|c|c|c|c|c|c|c|c|c|c|}
\hline \multirow{2}{*}{ Parameter } & \multirow{2}{*}{ Unit } & \multicolumn{3}{|c|}{ RW } & \multicolumn{3}{|c|}{ MWCNT-PP } & \multicolumn{3}{|c|}{ MWCNT-PE } & \multicolumn{3}{|c|}{ GAC-WG12 } \\
\hline & & Average & Min & Max & Average & Min & Max & Average & Min & Max & Average & Min & Max \\
\hline $\mathrm{pH}$ & - & - & 8.1 & 8.2 & - & 8.0 & 8.3 & - & 5.2 & 8.3 & - & 7.9 & 8.3 \\
\hline $\mathrm{C}_{340}$ & $\mathrm{gPt} / \mathrm{m}^{3}$ & 25.2 & 16.1 & 32.5 & 25.7 & 14.0 & 34.9 & 25.1 & 13.9 & 34.2 & 12.6 & 4.4 & 19.3 \\
\hline $\mathrm{C}_{410}$ & $\mathrm{gPt} / \mathrm{m}^{3}$ & 61.6 & 37.0 & 81.5 & 62.4 & 31.0 & 88.9 & 62.1 & 30.7 & 87.8 & 35.9 & 12.3 & 54.4 \\
\hline $\mathrm{UV}_{254}$ & $\mathrm{~m}^{-1}$ & 16.7 & 11.8 & 20.7 & 16.7 & 10.6 & 21.4 & 16.7 & 10.6 & 21.5 & 6.4 & 2.2 & 9.6 \\
\hline $\mathrm{UV}_{272}$ & $\mathrm{~m}^{-1}$ & 14.4 & 10.0 & 18.2 & 14.4 & 8.9 & 18.8 & 14.5 & 8.8 & 18.9 & 5.9 & 1.9 & 8.8 \\
\hline TOC & $\mathrm{gC} / \mathrm{m}^{3}$ & 6.06 & 5.02 & 7.32 & 5.81 & 3.95 & 7.25 & 6.00 & 3.97 & 7.24 & 1.33 & 0.10 & 1.88 \\
\hline DOC & $\mathrm{gC} / \mathrm{m}^{3}$ & 5.61 & 4.60 & 6.92 & 5.62 & 3.87 & 7.06 & 5.62 & 3.83 & 6.87 & 0.91 & 0.08 & 1.38 \\
\hline $2.3-2.5 \mathrm{kDa}$ & $\mathrm{g} / \mathrm{m}^{3}$ & 5.72 & 4.86 & 6.36 & 7.70 & 4.80 & 14.60 & 5.95 & 5.16 & 7.03 & 0.00 & 0.00 & 0.00 \\
\hline $1.8-2.0 \mathrm{kDa}$ & $\mathrm{g} / \mathrm{m}^{3}$ & 10.54 & 9.87 & 11.46 & 11.11 & 8.41 & 14.07 & 10.62 & 9.57 & 11.63 & 0.00 & 0.00 & 0.00 \\
\hline $0.7-0.9 \mathrm{kDa}$ & $\mathrm{g} / \mathrm{m}^{3}$ & 8.09 & 7.34 & 8.69 & 8.10 & 6.76 & 9.29 & 8.00 & 7.18 & 8.89 & 0.00 & 0.00 & 0.00 \\
\hline $0.5-0.7 \mathrm{kDa}$ & $\mathrm{g} / \mathrm{m}^{3}$ & 0.98 & 0.57 & 1.85 & 0.92 & 0.44 & 1.85 & 0.92 & 0.45 & 1.98 & 0.11 & 0.00 & 0.23 \\
\hline$<0.1 \mathrm{kDa}$ & $\mathrm{g} / \mathrm{m}^{3}$ & 1.10 & 0.33 & 1.61 & 1.52 & 0.55 & 2.76 & 1.43 & 0.66 & 2.38 & 0.33 & 0.00 & 0.95 \\
\hline SUVa & $\mathrm{m}^{2} / \mathrm{g}$ & 2.95 & 2.57 & 3.44 & 3.00 & 2.48 & 3.25 & 3.02 & 2.40 & 3.20 & 9.63 & 4.18 & 36.88 \\
\hline
\end{tabular}

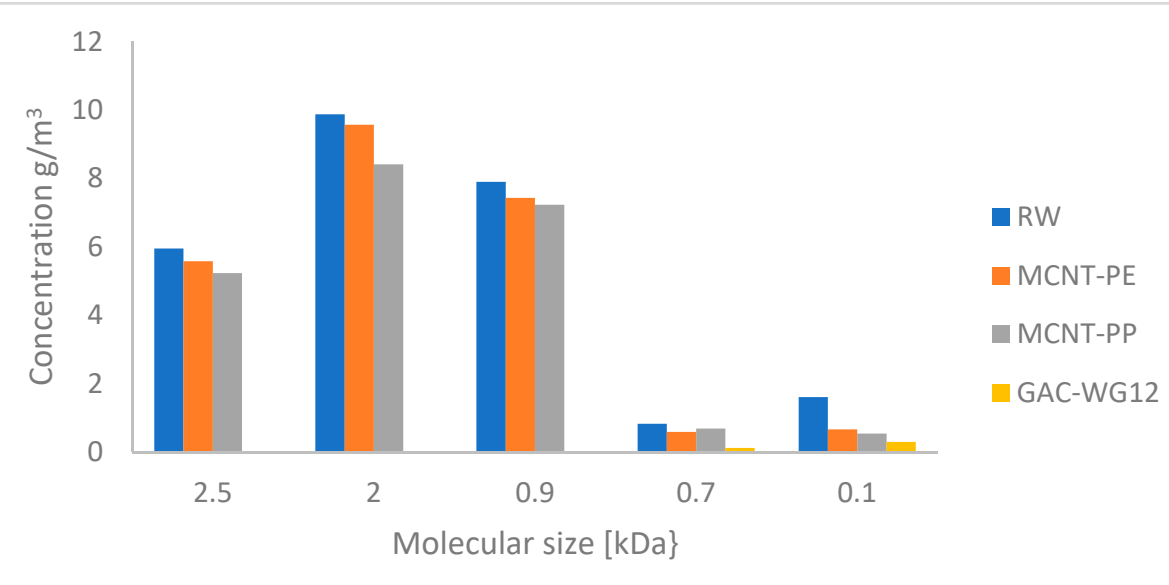

Figure 4. Distribution of molecular weight in raw water and filtrates.

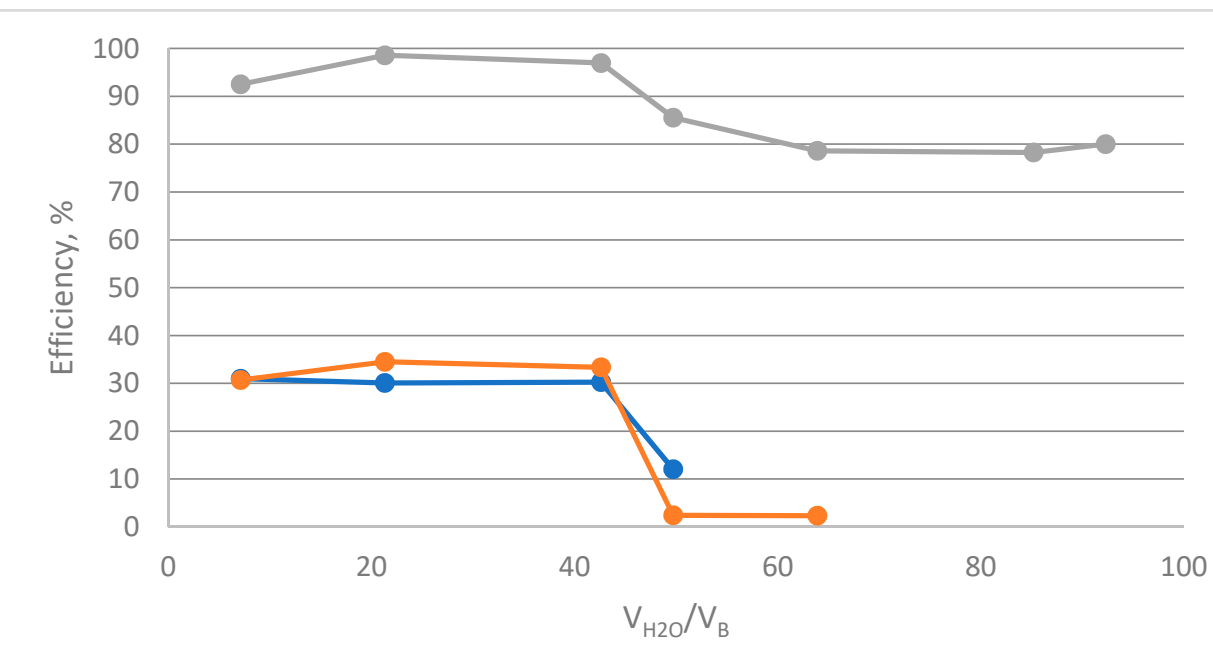

Figure 5. A comparison of the DOC removal effectiveness during the adsorption process. 
At the same time, the exhaustion of the absorption capacity of the MWCNT-PP bed was found after a volume of water corresponding to just 42 bed volumes had flowed through the bed. On the other hand, in the case of MWCNT-PE, the bed operating time was longer; however, its effectiveness was insignificant.

On the other hand, comparing the effectiveness of sorbents containing carbon nanotubes with granulated activated carbon show a low utility of CNTs in water treatment. This may be due to the inhibited contact of water with MWCNTs and the partial limiting of the sorption surface by polymers on which the CNTs were deposited. The second point is a selective removal of an organic particle only on low molecular weight from water on nanosorbents. These particles are a minority fraction of organic molecules.

The comparison of sorption capacity of used adsorbents and the efficiency of organic substances removal on used adsorbents were calculated. The unit sorption capacity comparison eliminates the influence difference in quantity used adsorbents in bed. In this way attention should be paid to the fact that during the first hour the quantity of adsorbed contamination was similar in all three beds. The quantity of adsorbed pollution increased on GAC-WG12 during the whole test, but for MWCNT-PE after $5 \mathrm{~h}$ and for MWCNT-PP after $6 \mathrm{~h}$ we observed depletion of sorption capacity (Figure 6). In case of both nanosorbents unit sorption capacity was significantly lower to GAC-WG12. It can be explained by non-selectivity organic substances removal by GAC-WG12.

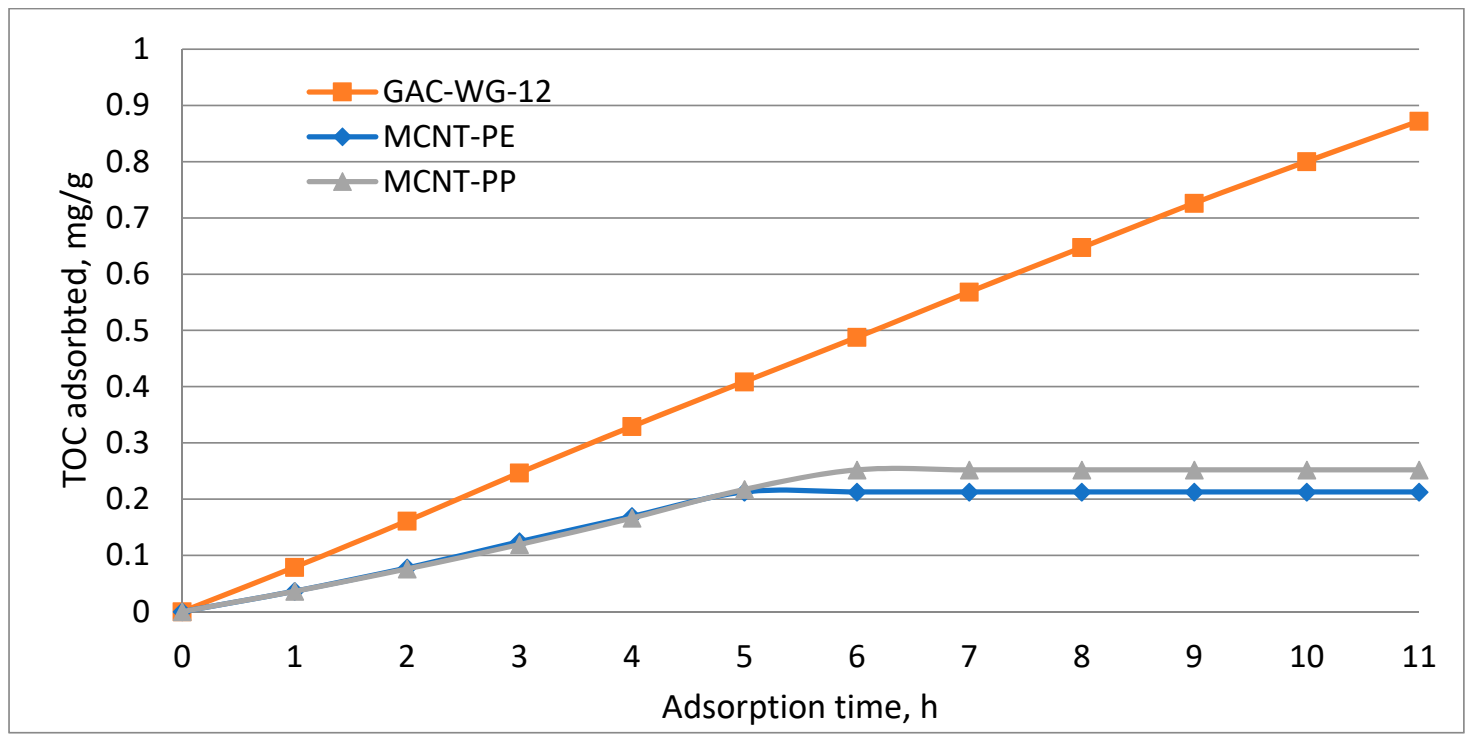

Figure 6. Amount of retained organic substances per $1 \mathrm{~g}$ of sorbents.

The effectiveness that was found in removing total organic carbon per $1 \mathrm{~g}$ of nanosorbents sorbent for humic acids was smaller than that found for other chosen organic substances [17] in the range of $87-400 \mathrm{mg} / \mathrm{g}$ [29].

The lower effectiveness that was found for nanosorbents may testify to an improper joining of components, an insufficient cleaning of CNTs [30] or process operating conditions that limit the use of the sorption potential.

It was found that from the three compared sorbents, GAC-WG12 removed molecules of all of the analyzed molecular weight (Figure 7), and this effectiveness did not reach $100 \%$ only for molecules smaller than $0.1 \mathrm{kDa}$ and in the range of $0.5-0.7 \mathrm{kDa}$. On the other hand, sorbents containing nanotubes showed a low effectiveness in removing substances with the highest (Table 1) and lowest analyzed molecular weight. Kilduff et al. [31] showed; however, carbon nanotubes show a high effectiveness in removing substances with a small molecular weight. In contrast Hyung and Kim [17] showed that carbon nanotubes most effectively remove substances with a large molecular weight. This means 
that the effectiveness in removing organic substances is determined by properties other than aromaticity or functional group type.

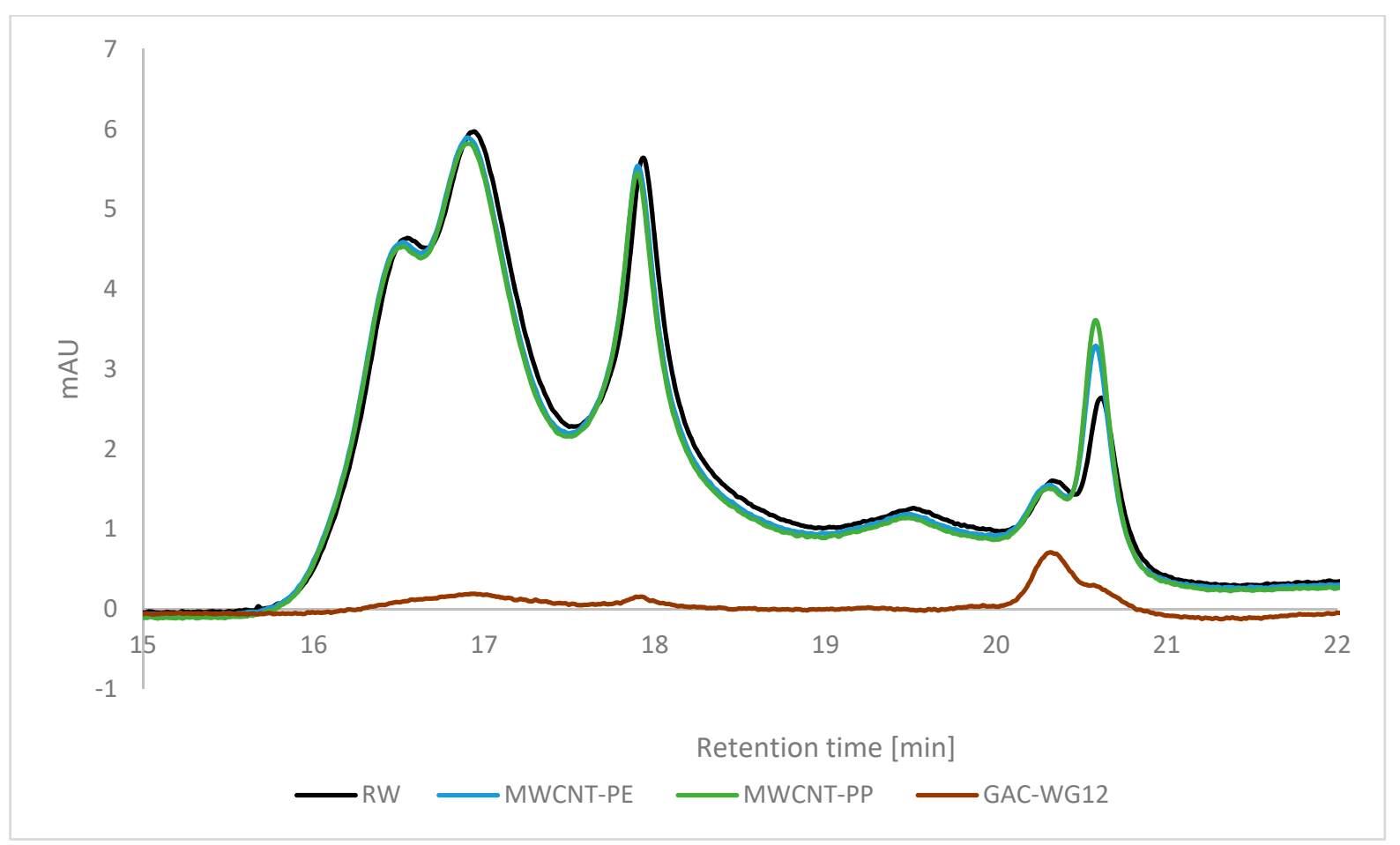

Figure 7. Chromatograph of the molecular size distribution in raw and post-adsorption water.

Among the substances removed on the adsorbents containing carbon nanotubes, molecules in the range of 0.5-0.7 kDa dominated (Figure 8).

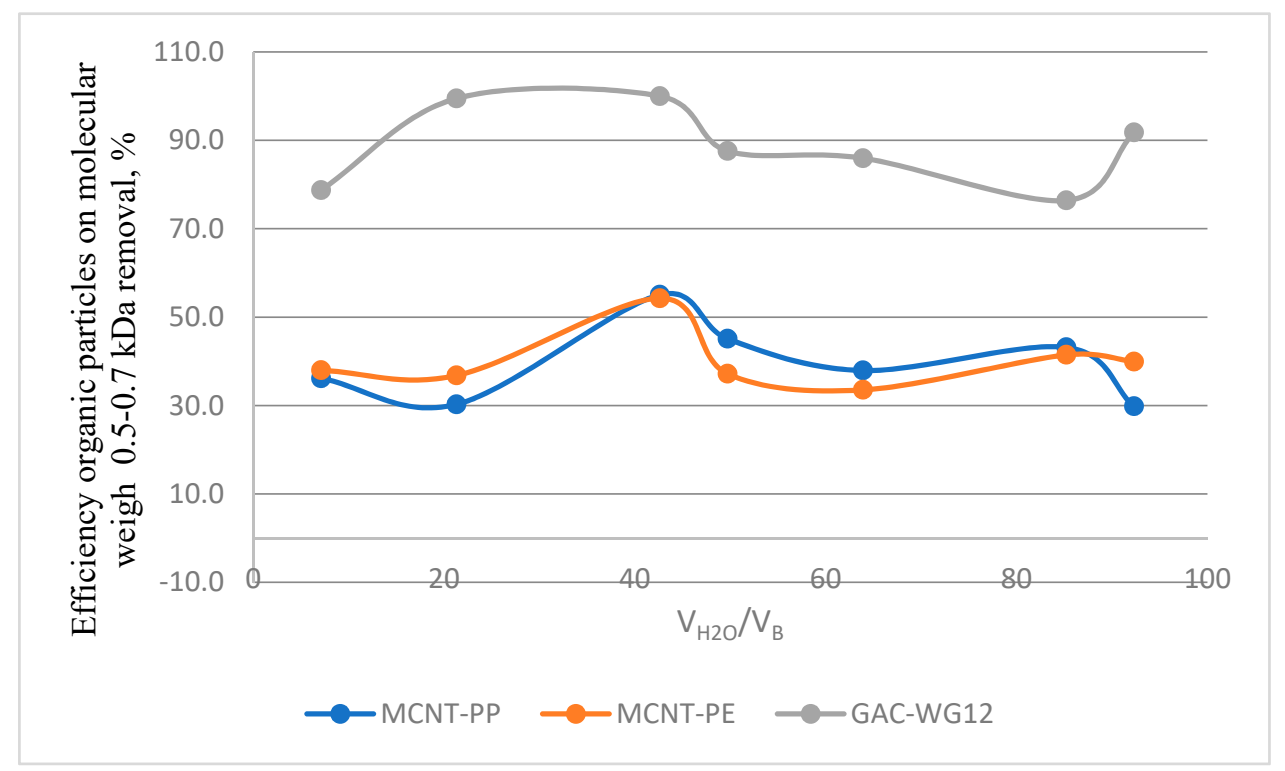

Figure 8. Effectiveness in removing organic substances with molecular weight of $0.5-0.7 \mathrm{kDa}$.

The results that were obtained, and the fact that low and medium molecular weight compounds were removed, are confirmed by studies of effectiveness in removing organic substances that showed that when using carbon nanotubes, humic substances are more effectively removed than fulvic acids [17]. 
A consequence of the removal of substances of varying molecular weight on GACWG12 was a significant increase in the SUVa values in filtrate after adsorption on this sorbent. On the other hand, the effective elimination of molecules of only a molecular weight of $0.5-0.7 \mathrm{kDa}$ on nanoadsorbents caused only insignificant changes in the values of SUVA in filtrates from these two adsorption columns (Figure 9).

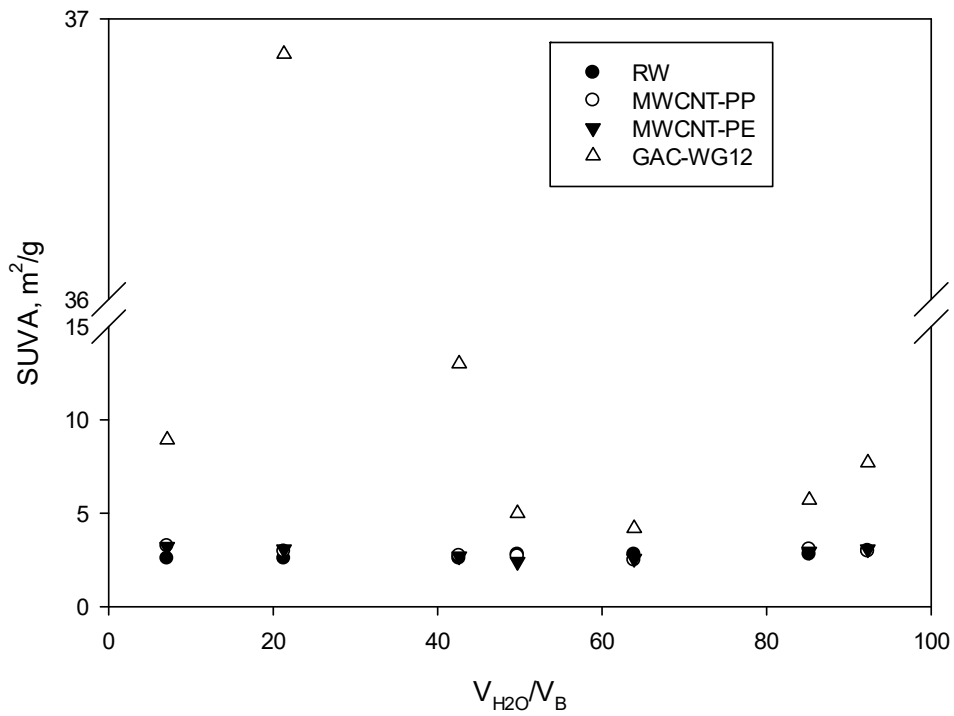

Figure 9. The specific UV absorbance values in raw and filtered water.

As Werschkun et al. [32] have shown, high UV absorbance values at both $254 \mathrm{~nm}$ and $272 \mathrm{~nm}$ in raw water testify to a large aromatic substance content. This means that aromatic substances dominated among the organic substances in raw water, which testifies to their susceptibility to adsorption. This hypothesis is confirmed by the decrease in UV absorbance in all filtrate samples. Similar results were obtained by Hyung and Kim [17], who have shown, that the effectiveness of nanotubes in removing organic substances increases with an increase in the aromaticity of substances in water.

Regardless of the effectiveness in removing organic substances, for all three of the sorbents aromatic substances were decisive in determining the dissolved organic carbon content, which is confirmed by the relationship that was found between DOC content and these absorbances (Figure 10a,b).

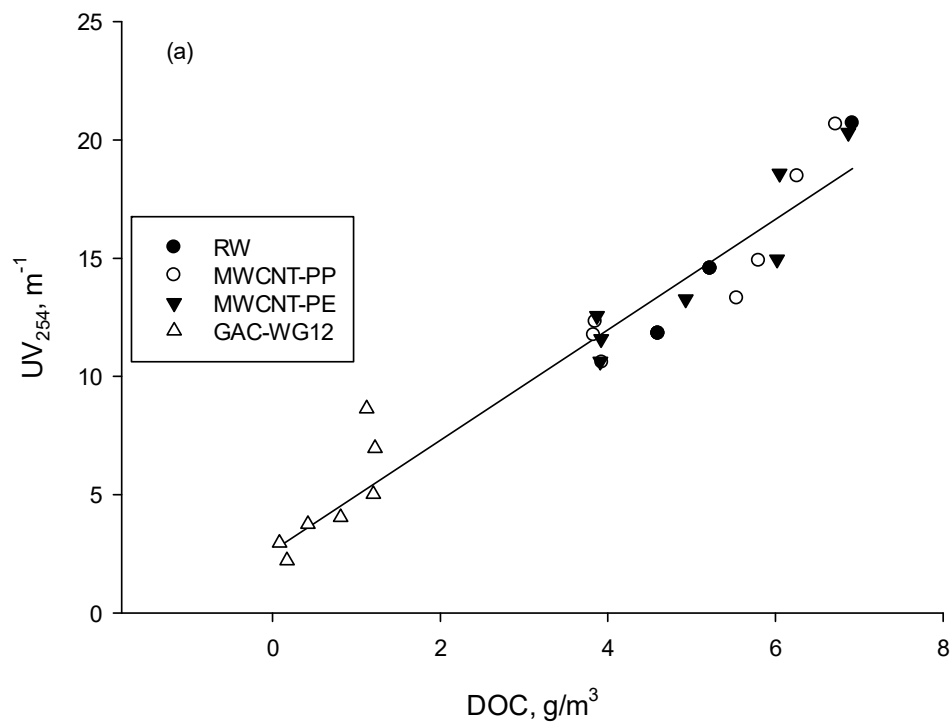

Figure 10. Cont. 


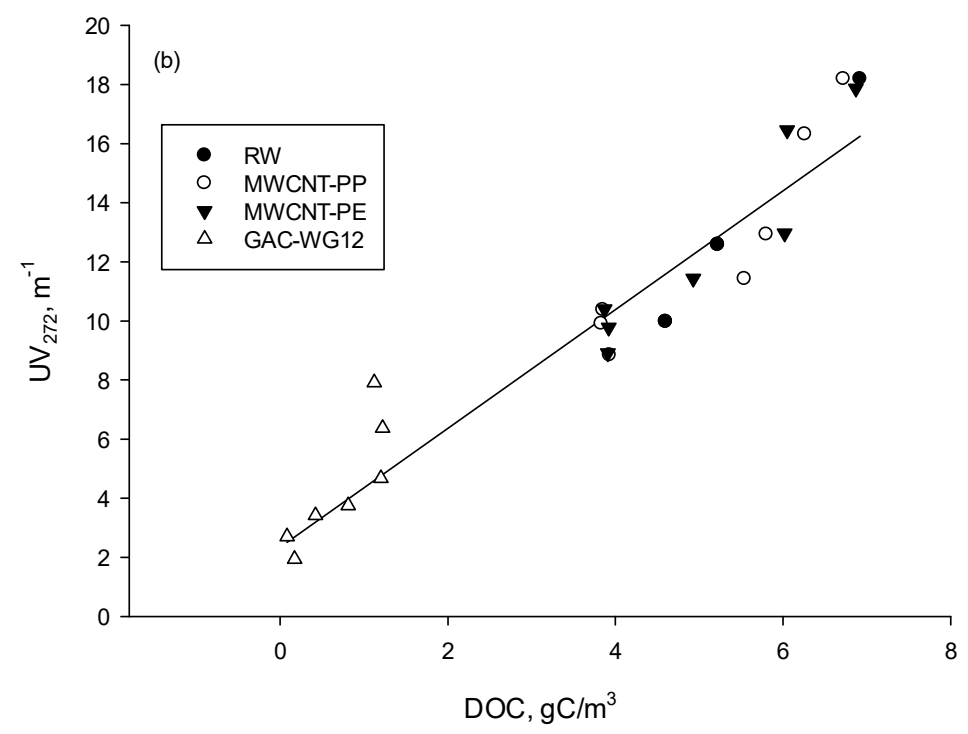

Figure 10. Relationship between (a) $\mathrm{UV}_{254}$ and DOC (b) $\mathrm{UV}_{272}$ and DOC.

\section{Conclusions}

Organic substances removal was significantly less effective for sorbents containing carbon nanotubes than for granulated activated carbon.

The operating time of nanosorbents beds is very short, which limits significantly the use of these materials in flow conditions, similar to that used in water treatment plants. Sorbents containing carbon nanotubes remove mainly molecules with a low molecular weight $(0.5-0.7 \mathrm{kDa})$. However, they do not ensure the removal of medium and large molecules. It limits significantly effectiveness of natural organic matter (NOM) removal from water.

The effectiveness of carbon nanosorbents was independent of the base material on which the carbon nanotubes were deposited.

The unit sorption capacity of GAC-WG12 was significantly larger than the one of sorbents containing CNTs, which indicates a possibility of increasing their effectiveness in removing organic substances by the use of higher filtration beds, but it would not be economically reasonable. The CNTs sorbents can be used as the selective sorbents for low molecular weight humic substances.

Author Contributions: Conceptualization, M.W.; methodology, M.W., A.S.-P. and Z.F.; formal analysis, M.W.; writing — original draft preparation, M.W., Z.F. and A.S.-P.; writing—review and editing, M.W.; visualization, M.W., Z.F. and A.S.-P. All authors have read and agreed to the published version of the manuscript.

Funding: This research received no external funding.

Conflicts of Interest: Authors decleare no confict of interest.

\section{References}

1. Adamski, W.; Szlachta, M. Technologies for the elimination of natural organic substances found in waters (Technologie eliminacji naturalnych substancji organicznych występujacych w wodach). Technol. Wody 2011, 1, 17. Available online: http:/ /yadda.icm. edu.pl/yadda/element/bwmeta1.element.baztech-article-BPC2-0001-0001 (accessed on 5 July 2021).

2. Aeschbacher, M.; Graf, C.; Schwarzenbach, R.P.; Sander, M. Antioxidant properties of humic substances. Environ. Sci. Technol. 2012, 46, 4916-4925. [CrossRef] [PubMed]

3. Grzegorczuk-Nowacka, M. Application of activated carbons in water and wastewater treatment (Zastosowanie wegli aktywnych w oczyszczaniu wody i ścieków). Technol. Wody 2010, 1, 27-35. Available online: http://yadda.icm.edu.pl/yadda/element/ bwmeta1.element.baztech-article-BPC2-0003-0003 (accessed on 5 July 2021). (In Polish).

4. Jeong, C.H.; Wagner, E.D.; Siebert, V.R.; Anduri, S.; Richardson, S.D.; Daiber, E.J.; McKague, A.B.; Kogevinas, M.; Villanueva, C.; Goslan, E.H.; et al. Occurrence and toxicity of disinfection byproducts in European drinking waters in relation with the HIWATE epidemiology study. Environ. Sci. Technol. 2012, 46, 12120-12128. [CrossRef] [PubMed] 
5. Sander, M.; Pignatello, J.J. Characterization of charcoal adsorption sites for aromatic compounds: Insights drawn from singlesolute and bi-solute competitive experiments. Environ. Sci. Technol. 2005, 39, 1606-1615. [CrossRef] [PubMed]

6. Tan, I.A.W.; Ahmad, A.L.; Hameed, B.H. Adsorption of basic dye using activated carbon prepared from oil palm shell: Batch and fixed bed studies. Desalination 2008, 225, 13-28. [CrossRef]

7. Yousef, R.I.; El-Eswed, B.; Ala'a, H. Adsorption characteristics of natural zeolites as solid adsorbents for phenol removal from aqueous solutions: Kinetics, mechanism, and thermodynamics studies. Chem. Eng. J. 2011, 171, 1143-1149. [CrossRef]

8. Choi, G.G.; Jung, S.H.; Oh, S.J.; Kim, S.J. Total utilization of waste tire rubber through pyrolysis to obtain oils and $\mathrm{CO}_{2}$ activation of pyrolysis char. Fuel Process. Technol. 2014, 123, 57-64. [CrossRef]

9. Gupta, V.K.; Nayak, A. Cadmium removal and recovery from aqueous solutions by novel adsorbents prepared from orange peel and $\mathrm{Fe}_{2} \mathrm{O}_{3}$ nanoparticles. Chem. Eng. J. 2012, 180, 81-90. [CrossRef]

10. Saleh, T.A.; Gupta, V.K. Functionalization of tungsten oxide into MWCNT and its application for sunlight-induced degradation of Rhodamine BJ Colloid Interf. Science 2011, 362, 337-344. [CrossRef]

11. Allen-King, R.M.; Grathwohl, P.; Ball, W.P. New modelling paradigms for the sorption of hydrophobic organic chemicals to heterogeneous carbonaceous matter in soils, sediments, and rocks. Adv. Water Resour. 2002, 25, 985-1016. [CrossRef]

12. Yang, K.; Zhu, L.; Xing, B. Adsorption of polycyclic aromatic hydrocarbons by carbon nanomaterials. Environ. Sci. Technol. 2006, 40, 1855-1861. [CrossRef]

13. Yang, K.; Xing, B.S. Adsorption of organic compounds by carbon nanomaterials in aqueous phase: Polanyi theory and its application. Chem. Rev. 2010, 110, 5989-6008. [CrossRef]

14. Raymundo-Pinero, E.; Cazorla-Amorós, D.; Linares-Solano, A.; Delpeux, S.; Frackowiak, E.; Szostak, K.; Béguin, F. High surface area carbon nanotubes prepared by chemical activation. Carbon 2002, 40, 1614-1617. [CrossRef]

15. Chen, W.; Duan, L.; Zhu, D.Q. Adsorption of polar and nonpolar organic chemicals to carbon nanotubes. Environ. Sci. Technol. 2007, 41, 8295-8300. [CrossRef]

16. Lin, D.H.; Xing, B.S. Adsorption of phenolic compounds by carbon nanotubes: Role of aromaticity and substitution of hydroxyl groups. Environ. Sci. Technol. 2008, 42, 7254-7259. [CrossRef] [PubMed]

17. Hyung, H.; Kim, J.H. Natural organic matter (NOM) adsorption to multi-walled carbon nanotubes: Effect of NOM characteristics and water quality parameters. Environ. Sci. Technol. 2008, 42, 4416-4421. [CrossRef] [PubMed]

18. Ajmani, G.S.; Goodwin, D.; Marsh, K.; Fairbrother, D.H.; Schwab, K.J.; Jacangelo, J.G.; Huang, H. Modification of low pressure membranes with carbon nanotube layers for fouling control. Water Res. 2012, 46, 5645-5654. [CrossRef]

19. .Celik, E.; Park, H.; Choi, H.; Choi, H. Carbon nanotube blended polyethersulfone membranes for fouling control in water treatment. Water Res. 2011, 45, 274-282. [CrossRef] [PubMed]

20. Brady-Estévez, A.S.; Schnoor, M.H.; Kang, S.; Elimelech, M. SWNT-MWNT hybrid filter attains high viral removal and bacterial inactivation. Langmuir 2010, 26, 19153-19158. [CrossRef] [PubMed]

21. Jia, G.; Wang, H.; Yan, L.; Wang, X.; Pei, R.; Zhao, Y.; Guo, X. Cytotoxicity of carbon nanomaterials: Single-wall nanotube, multi-wall nanotube, and fullerene. Environ. Sci. Technol. 2005, 39, 1378-1383. [CrossRef]

22. Liu, X.; Wang, M.; Zhang, S.; Pan, B. Application potential of carbon nanotubes in water treatment: A review. J. Environ. Sci. 2013, 25, 1263-1280. [CrossRef]

23. Shimizu, Y.; Ateia, M.; Yoshimura, C. Natural organic matter undergoes different molecular sieving by adsorption on activated carbon and carbon nanotubes. Chemosphere 2018, 203, 345-352. [CrossRef]

24. Wolska, M.; Machi, J.; Szerzyna, S.; Mołczan, M.; Adamski, W.; Wiśniewski, J. Effect of ozonation on organic substance removal efficiency during adsorption. Desalination Water Treat. 2018, 117, 101-107. [CrossRef]

25. Weishaar, J.L.; Aiken, G.R.; Bergamaschi, B.A.; Fram, M.S.; Fujii, R.; Mopper, K. Evaluation of specific ultraviolet absorbance as an indicator of the chemical composition and reactivity of dissolved organic carbon. Environ. Sci. Technol. 2003, 37, 4702-4708. [CrossRef]

26. Wu, Y.; Zhou, S.; Qin, F.; Peng, H.; Lai, Y.; Lin, Y. Removal of humic substances from landfill leachate by Fenton oxidation and coagulation. Process Saf. Environ. Prot. 2010, 88, 276-284. [CrossRef]

27. Ghasemzadeh, G.; Momenpour, M.; Omidi, F.; Hosseini, M.R.; Ahani, M.; Barzegari, A. Applications of nanomaterials in water treatment and environmental remediation. Front. Environ. Sci. Eng. 2014, 8, 471-482. [CrossRef]

28. Ødegaard, H.; Østerhus, S.; Melin, E.; Eikebrokk, B. NOM removal technologies-Norwegian experiences. Drink. Water Eng. Sci. 2010, 1, 1-9. [CrossRef]

29. Mishra, A.K. (Ed.) Application of Nanotechnology in Water Research; John Wiley Sons: Hoboken, NJ, USA, 2014. [CrossRef]

30. Ismail, A.F.; Goh, P.S.; Tee, J.C.; Sanip, S.M.; Aziz, M. A review of purification techniques for carbon nanotubes. Nano 2008, 3, 127-143. [CrossRef]

31. Kilduff, J.E.; Karanfil, T.; Weber, W.J. Competitive interactions among components of humic acids in granular activated carbon adsorption systems: Effects of solution chemistry. Environ. Sci. Technol. 1996, 30, 1344-1351. [CrossRef]

32. Werschkun, B.; Sommer, Y.; Banerji, S. Disinfection by-products in ballast water treatment: An evaluation of regulatory data. Water Res. 2012, 46, 4884-4901. [CrossRef] [PubMed] 